\title{
Wealth Creation In The Recent Merger Boom, The Canadian Evidence
}

Ayse Yuce, (E-mail: ayuce@ryerson.ca), Ryerson University, Canada

Alex Ng, (E-mail: nga@unbc.ca), University of Northern British Columbia, Canada

\begin{abstract}
We examine the merger announcements of Canadian companies between 1994 and 2000 during an exceptional merger boom. Our results show that both target companies and the acquirer companies obtain significant positive abnormal returns at this time period. However, in the long run, we observe that abnormal returns diminish to become significant and negative for acquiring companies and diminish to be non-significant and positive for target companies. We find acquiring companies to have significantly higher risk that purchase private targets compared with public targets, despite non-significant differences in returns. Our large sample study updates and fills a void in Canadian merger studies during this important and recent time period in merger and acquisitions.
\end{abstract}

\section{Introduction}

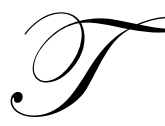

he study of mergers and acquisitions focuses on understanding what motivates managers to engage in this type of activity and the impact that mergers and acquisitions have on shareholder returns. Mergers and acquisitions are an important means to grow a company. Managers' motivations for mergers could be empire building through growth in size, (Mueller, 1969) sales and assets (Berle and Means, 1932) (Schipper and Thompson, 1983). Managers choose to merge or acquire with others for potential market gains, for overcoming technological barriers, and for gaining a technological edge, as well as for building diversification on existing strengths. Managers are also pursuing efficiency improvements through mergers and acquisitions. Efficiency improvements can be gained from synergy of target and bidding firms due to economies of scale and use of excess capacity. For example, vertical mergers create economies of scale by enabling more efficient coordination of the members of the vertical chain. Berry (2000) and Williamson (1971) further promotes that vertical mergers increase shareholder returns by creating internal transfer pricing transactions. Managers may pursue mergers and acquisitions to lower the cost of capital and improve shareholder returns. They may see that acquisitions can reduce the probability of default due to the co-insurance effect (Lewellen, 1971) thus reducing bankruptcy costs and increasing the debt capacity of the combined firm. By increasing debt capacity, a manager can reduce the cost of capital through interest tax shields and add value to the firm. Levy and Sarnat (1970) support this managerial motivation. They find that in conglomerate mergers, large firms enjoy significant cost savings when securing their financing needs. These cost savings presumably reflect, at least in part, the reduction in lenders' risk achieved through diversification. However, recent studies (Lang and Stulz (1994), Berger and Ofek (1995), Maquieira, Megginson and Nail (1998)) challenge value creation in conglomerate mergers; that there are no synergies created through diversification or horizontal mergers.

For the above motivations and more, Canadian managers are very active in mergers and acquisitions between 1994 and 2000. We examine the impact of mergers on Canadian shareholder returns. In contrast to US studies of shareholder returns, Canadian studies appear to consistently show positive and significant returns to acquiring firm shareholders. Differences in Canadian industry, capital markets and regulations appear to justify the difference in the Canadian experience. Yet, the Canadian studies are few and more evidence is needed; this paper provides the most current evidence from the recent worldwide merger boom of the 1990's-2000. Moreover, we go further than existing studies to examinine the impact of acquiring public vs. private companies on shareholder returns. 
The first part of the paper summarizes the key research findings from the literature on mergers and acquisitions. We then formulate our hypotheses, describe the sample of firms, data acquisition, and analytical methodology and present our results. We conclude the paper with a discussion of directions for further research.

\section{Previous Studies}

Various researchers (Dodd (1980), Dennis and McConnell (1986)) conclude that as a result of merger, the returns go to target firms. Returns to target shareholders range from 20-30 \% (Dodd and Ruback (1977), Dodd (1980), Bradley and Wakeman (1983), Jensen and Ruback (1983), Malatesta (1983)). On the other hand, the impact of merger on returns for the acquiring firms has largely been either significant negative abnormal returns (Dodd (1980), Firth (1980), and Eger (1983)) or non-significant positive abnormal returns. (Asquith (1983), Eckbo (1983), Dennis and McConnell (1986) and Amihud, Dodd and Weinstein (1986)).

Travlos (1987) studies the impact of form of payment made by an acquiring firm on shareholder returns in a merger. He finds significant differences in abnormal returns between acquirers making stock-exchange offers versus cash offers. That is, acquirers making cash offers achieve normal returns; whereas, acquirers making stockexchange offers achieve abnormal negative returns. Franks, Harris and Mayer (1988) explain "equity in acquisitions conveys bad news, while cash conveys good news". Indeed, Travlos (1987) also supports this information signaling hypotheses to explain different returns for acquiring firms making cash offers versus stock offers.

The method of merger also has an impact on shareholder returns. Tender offers are made directly to company shareholders for a controlling stake of the company. These tend to be unfriendly takeovers. Merger offers are negotiated between top management of the acquiring and target companies; these tend to be friendly takeovers (Bruner, 2002). Jensen and Ruback (1983) find that shareholders of target firms in tender offers receive about twice the returns of those receiving merger offers. Tender offers do pay.

While most event studies on the impact of mergers on shareholder returns are done in North America, there is also similar evidence around the world. Doukas and Travlos (1988) examine the impact of international mergers and acquisitions on U.S. company shareholder returns. Their findings are interesting because studies on domestic acquisitions often find non-significant positive returns for the acquiring firm; it is the target firm that receives the abnormal returns. In contrast, they find that when a U.S. company acquires a company in another country, significant and positive returns are gained. These abnormal returns are larger when firms expand into new industry and geographic markets - especially with those countries that are less developed than the U.S. economy. Further research of Manzon, Sharp and Travlos (1994) find that the abnormal returns to U.S. companies making international acquisitions are related to tax differences in the international tax status of acquiring firms.

Looking at foreign companies buying U.S. companies, such mergers and acquisitions result in significant and positive returns to shareholders of both acquiring and target company shareholders. (Eun, Kolodny, and Scheraga, 1996) Shareholders of the U.S. target companies earn significant wealth gains regardless of the nationality of foreign acquirers. In particular, their study show that Japanese acquisitions generate the largest wealth gains to both target and acquiring company shareholders. A compelling motivation for foreign managers was gaining the U.S. target firms R\&D capabilities and access to a more lucrative US market.

The Canadian experience of merger studies date back to 1983. Consistent with the research on mergers and acquisitions in the United States, Canadian studies also show that target firms gain more than acquirers. On average, gains are 9-23\% for target firms. Eckbo (1986), Calvet and Lefoll (1987) using Canadian monthly data, find that mergers result in significant gains for shareholders of acquiring and target firms. Masse, Hanrahan and Kushner (1988), using daily data, find that the timing of the gains is focused in the month prior to the merger announcement date. Masse, Hanrahan and Kushner (1990) conclude that the type of acquisition and method of payment do affect the shareholder returns for both the target and acquiring firms. They find shareholders of both target and acquiring companies receive gains. Shareholders of acquiring firms earn considerably less returns than those of target firms, both in tender and in merger offers. For target firms, tender offers pay double the returns to shareholders than mer- 
ger offers. The previous studies do show similarities in results with U.S. studies. Yet, Canadian studies and the industry do differ from the U.S. for these important respects. First, studies in Canada report positive and significant gains to acquiring companies; whereas, most merger studies on US companies report significant negative or nonsignificant returns to acquiring companies (Bruner, 2002). Second, Canadian capital markets, industries and companies are much smaller than the US. Canada is about one tenth the size in population as the United States. Third, "Canadian industrial markets are characterized by fewer firms and greater concentration of output relative to the U.S. markets" (Eckbo, 1992). He finds that the mean industry concentration ratio is $48 \%$ in Canada and $33 \%$ in the U.S. for horizontal mergers. Finally, anti-trust laws are more developed and strict in the U.S. compared to Canada. Eckbo, 1992 points out that the enforcement of anti-trust policy since the 1950's "significantly deter horizontal merger activity" in the United States. On the other hand, Canada has fewer regulations on mergers and acquisitions up until 1985. Hence, for the reasons that Canadian and U.S. industry, capital markets and regulations do differ, that Canadian studies on M\&A are justifiably different from U.S. studies.

Since the 1980's decade of merger activity, there has been a worldwide merger boom. Pryor (2001) characterizes this merger boom in the 1990's as a distinct decade of mergers from the 1980's in the US, Canada and OECD countries. Indeed, in the 1990's, we witness some spectacular merger activities such as the frenetic initial public offerings and subsequent acquisitions of multitudes of dot.com companies, the prominence of global business and transnational mergers, and unprecedented mega-merger deals such as the 165 billion AOL-Time Warner deal. Quantitatively, Pryor (2001) estimates that between 1992 and 1999, the total recorded value of merger deals grew at an annual rate of 35.7 percent, and from 1985 to 1999, the total volume of mergers rose at 20.8 percent annually. In addition to the increases in the total value and volume dimensions of merger activities, Pryor (2001) also notes the increasing importance of the mega-deals of global companies' mergers. There has been an important shift in merger activities to other industries since the 1980's. "The focus of mergers has shifted from a predominance in manufacturing and mining to other sectors, particularly communications, financial, and services" (Pryor, 2001). Moreover, he finds that the type of merger, conglomerate, vertical and horizontal, has shifted in the 1990's. Prior to the merger boom in 1985, he observes that vertical and conglomerate mergers are dominant. After the merger boom since 1985 , horizontal mergers are clearly dominant. The dot.com bubble is also noteworthy of the late 1990's as we wonder about its merger implications.

The 1990's is also a time when global business emerged to prominence particularly with the establishment of the North American Free Trade Agreement in 1994. In this regard, "the worldwide shares of merger activity in Canada and the United States have noticeably decreased, while the share of merger activity in the OECD nations have considerably increased" (Pryor, 2001). Finally, to truly understand the exceptional nature of this merger boom, Pryor (2001) finds this merger boom to be greater than any other merger boom in past U.S. history. He notes that this merger boom is much greater (measured in terms of number) than previous merger booms with peaks around 1900, 1929, 1963 and the early 1980's (Golbe and White, 1993).

Given this extraordinary period of mergers in the 1990's, there is reason to believe in changes in the return patterns to acquirer and target companies over time. Bruner, 2002 observes that there is "a slight tendency for returns to decline over time: returns appear to be higher (more positive) in the 1960's and 1970's than in the 1980's and 1990's, except for deals in technology and banking, where returns to bidders increase in the 1990s." As is also reported by Bradley, Desai and Kim, 1988 that average announcement returns to acquirers fell from $4.1 \%$ in the 1963 to 1968 period, to $-2.9 \%$ in the 1981-1984 period. These suggest that there is a temporal effect on M\&A performance. While there are numerous empirical studies done in the 1990's in the U.S., there are few done in Canada between 1990-2001. These few studies deserve mention; there are two. Eckbo (1992) uses Canadian merger data from 1964 to 1982 in his article, "Mergers and the Value of Antitrust Deterrence". Jabbour, Jalilvand, and Switzer (2000) uses Canadian merger data from 1985-1995 in their article, "Pre-bid price run-ups and insider trading activity: Evidence from Canadian acquisitions". Our paper examines a sample period of 1994-2000. In times of a merger boom, we hypothesize that mergers and acquisitions create significant and positive returns to shareholders of both acquirer and target companies. There is money to be made in mergers during this booming and prosperous period of mergers unlike other time periods. Recall, that many previous studies report significant and negative returns or nonsignificant returns to acquiring company shareholders. Our paper serves to fill a void in the empirical work in Can- 
ada that are largely done in the 1980's to gain insight of a unique worldwide merger boom that occurred between 1985 and the end of the millennium.

We also examine the impact of merging or acquiring public versus private companies on returns to shareholders of acquiring firms. Can the market value acquisitions differently under asymmetric information conditions? These conditions exist when acquiring firms buy privately owned companies in which the acquiring firm knows far more information about the private company than the market. Unlike publicly traded companies, which provide accessible company information to market investors, private companies provide no such information. Hence, asymmetric information about the value of a private target company exists between the acquirer and the market. Under this condition then, are shareholders of acquiring companies rewarded any differently for acquiring private companies versus public companies? This aspect is highly relevant to the reality of mergers and acquisitions because we find in our Canadian sample that the clear majority of acquired target companies were private companies. Furthermore, previous empirical studies seem to treat all acquirers, whether they bought public or private companies, with the resulting return patterns as the same. We hypothesize that there would be a difference in returns between acquirers that buy publicly companies, and acquirers that buy private companies.

\section{Hypotheses Testing:}

We test the following hypotheses for the merger announcements. First we examine whether mergers and acquisitions create abnormal returns for the target company shareholders:

$\mathbf{H}_{1}$ : $\quad \mathrm{Ha}=$ Mergers and acquisitions do create positive and significant abnormal returns for target company shareholders.

Second, we test whether mergers and acquisitions create abnormal returns for the acquiring companies:

$\mathbf{H}_{2}$ : $\quad \mathrm{Ha}=$ Mergers and acquisitions do create significant and positive or negative abnormal returns for acquiring company shareholders.

Third, we examine whether private targets create significant and different returns than public ones for acquiring companies:

$\mathbf{H}_{3}: \quad \mathrm{Ha}=$ Private targets and Public targets create significant and different returns for acquirers.

\section{Event Study Methodology}

\subsection{Measurement}

Event studies examine the impact of merger announcements on abnormal returns to shareholders. The independent variable is defined as the time surrounding the merger announcement date, and we chose to measure 40 days before and 40 days after a merger announcement date. The dependant variable is defined as abnormal return. First raw returns are calculated for each day, which is the change in share price and any dividends paid, divided by the closing share price the day before. (Bruner, 2002) The abnormal return is simply the raw return less a benchmark return of a large stock index such as the TSE-300. The abnormal return, $\mathrm{AR}_{\mathrm{j}, \mathrm{t}}$ is defined as follows:

$$
A R_{j, t}=R_{j, t}-R_{b m, t}
$$

where $\mathrm{R}_{\mathrm{j}, \mathrm{t}}$ is the daily stock return and $\mathrm{R}_{\mathrm{bm}}$ is the benchmark portfolio return proxied by the total return on the TSE300 and represents the expected return of the stock in question. Acquirer and target company share prices are obtained from the DataStream database. The Toronto Stock Market Composite Total Return Index (TSE-300) is also 
obtained from the DataStream database. Finally, the market model is used to calculate abnormal returns in the traditional form.

Then, average abnormal returns are calculated as:

$A A R_{t}=\frac{\left(\sum_{j=1}^{n} A R_{j, t}\right)}{n}$

The cumulative abnormal return from the first day to the trading day, $\mathrm{s}$ is given by the following formula:

$C A R_{1, s}=\sum_{t=1}^{s} A A R_{t}$

\subsection{Data}

We examine the short-term (40 day) performance of Canadian mergers between 1994-2000. All Canadian mergers over this 6-year period are examined. The announcement dates, as well as auditor, investment banker and issue specific information is obtained from the Lexus Nexus database. As a basic criterion, companies first have to be publicly traded and have sufficient time series price data on Datastream. Some data are screened out because of the following reasons: 1- The stock is in the regional market, 2- the stock has not traded continuously, and 3- the companies are in the financial industry. Financial firms experience different return patterns than those of nonfinancial companies. Table 1 summarizes the number of companies examined in our sample.

Table 1

Sample Statistics of Canadian Public Companies in Mergers and Acquisitions, 1994-2000

\begin{tabular}{|l|c|c|}
\hline & Acquiring Companies & Target Companies \\
\hline Total Number of Listed Companies & 1565 & 281 \\
\hline Less Financial Service Companies & -204 & -39 \\
\hline Number of Companies Reported & $\mathbf{1 3 6 1}$ & $\mathbf{2 4 2}$ \\
\hline Average Transaction Value & $\$ 150,005,434$ & $\$ 284,143,753$ \\
\hline Percent Positive Returns & $53 \%($ CAR 0,2$)$ & $61 \%$ \\
\end{tabular}

As shown in Table 1, as a result of meeting our criteria, we are able to calculate returns on 1361 acquirer companies and 242 target companies. We acknowledge that there are far more Canadian acquiring companies compared with target companies. As we are examining publicly traded companies, it appears that the majority of Canadian target companies acquired were not publicly traded. The Percent Positive Returns shows the percentage of acquiring and target companies that show positive returns during the merger period of $\operatorname{CAR}(0,2)$. It appears that more target company shareholders earn positive returns compared with acquiring company shareholders.

\subsection{Analysis}

To accept or reject our hypotheses in this event study, we use the t-statistic to test for significance at the alpha $=.05$ level. In our first hypothesis, we hypothesize that targets will earn positive abnormal returns given that most studies have found this result. Consequently, we perform a one-tail t-test on our abnormal returns for significant differences. Because previous studies show that acquirers earn negative or positive returns, we perform a twotail t-test on abnormal returns for significant differences. In testing our third hypothesis that there would be differ- 
ences in returns to acquiring company shareholders as a result of purchasing private versus public targets, we use a two-tail t-test to compare abnormal return differences.

\section{Results and Interpretation}

\subsection{Performance of Target Firms}

We examine abnormal returns for 242 target companies' shareholders between 1994 and 2000 as shown in Table II and cumulative abnormal returns for the same shareholders in Table III. We find that target firm shareholders start earning significant excess returns as early as 2 weeks, on days -14 and -16 before the merger announcement day. Three days before the announcement day, the abnormal returns are also significant and positive at $0.96 \%$. The abnormal returns are 0.57 and $0.82 \%$ respectively on days -2 and -1 ; however, they are statistically non-significant. However, on the day of announcement, a significant and relatively large abnormal return is found, which is $4.42 \%$ mean abnormal return to target shareholders. There is also significant positive abnormal return, $1.19 \%$ two days after the announcement day.

As shown in Table III and Figure 1, our holding period returns or Cumulative Abnormal Returns (CAR), also support our alternate hypothesis that significant and positive abnormal returns go to target shareholders. The significant and positive CAR's have a range from 4.00 percent to 9.53 percent. The cumulative abnormal return for target companies within two day holding period (CAR 0,2) is $6.31 \%$, and this number goes as high as $8.73 \%$ for ten day holding period (CAR-5,5) beginning 5 days before the announcement day. Ten-day holding period starting from the announcement period (CAR 0,10) produces $4.00 \%$ abnormal return. Abnormal returns become non-significant for a three-week horizon; however, they never become negative for target company shareholders.

Table II

Target Company Abnormal Returns

\begin{tabular}{|c|c|c|c|c|c|c|}
\hline $\begin{array}{c}\text { Event } \\
\text { Day }\end{array}$ & $\begin{array}{c}\text { Abnormal } \\
\text { Return }\end{array}$ & t-statistic & $\begin{array}{c}\text { Event } \\
\text { Day }\end{array}$ & $\begin{array}{c}\text { Abnormal } \\
\text { Return }\end{array}$ & t-statistic \\
\hline-20 & $0.40 \%$ & 0.85 & & 1 & $0.70 \%$ & 1.14 \\
\hline-19 & $-0.17 \%$ & -0.41 & & 2 & $1.19 \%$ & $2.33 *$ \\
\hline-18 & $-0.17 \%$ & -0.36 & & 3 & $-0.63 \%$ & -1.30 \\
\hline-17 & $-0.77 \%$ & -1.45 & & 4 & $0.38 \%$ & 0.84 \\
\hline-16 & $0.92 \%$ & $2.20^{*}$ & & 5 & $-0.40 \%$ & -0.86 \\
\hline-15 & $0.18 \%$ & 0.44 & & 6 & $-0.22 \%$ & -0.58 \\
\hline-14 & $0.90 \%$ & $2.02^{*}$ & & 7 & $-0.15 \%$ & -0.40 \\
\hline-13 & $-0.36 \%$ & -0.73 & & 8 & $0.26 \%$ & 0.76 \\
\hline-12 & $0.47 \%$ & 1.17 & & 9 & $-0.61 \%$ & -1.35 \\
\hline-11 & $0.61 \%$ & 1.14 & & 10 & $-0.94 \%$ & -0.73 \\
\hline-10 & $-0.63 \%$ & -1.48 & & 11 & $-0.92 \%$ & $-1.91 *$ \\
\hline-9 & $0.79 \%$ & $1.84^{*}$ & & 12 & $0.07 \%$ & 0.18 \\
\hline-8 & $0.19 \%$ & 0.49 & & 13 & $-0.17 \%$ & -0.42 \\
\hline-7 & $0.10 \%$ & 0.31 & & 14 & $0.28 \%$ & 0.76 \\
\hline-6 & $-0.01 \%$ & -0.03 & & 15 & $0.41 \%$ & 1.19 \\
\hline-5 & $0.81 \%$ & $1.82^{*}$ & & 16 & $-0.05 \%$ & -0.12 \\
\hline-4 & $-0.08 \%$ & -0.20 & & 17 & $-0.19 \%$ & -0.43 \\
\hline-3 & $0.96 \%$ & $2.06^{*}$ & & 18 & $-0.14 \%$ & -0.35 \\
\hline-2 & $0.57 \%$ & 1.26 & & 19 & $-0.40 \%$ & -1.16 \\
\hline-1 & $0.82 \%$ & $1.66^{*}$ & & 20 & $0.20 \%$ & 0.58 \\
\hline 0 & $4.42 \%$ & $3.85^{*}$ & & & & \\
\hline
\end{tabular}


Table III

Target Company Cumulative Abnormal Returns

\begin{tabular}{|l|c|c|}
\hline CAR Range & $\begin{array}{c}\text { Abnormal } \\
\text { Return }\end{array}$ & t statistic \\
\hline $\operatorname{CAR}(-5,5)$ & $8.73 \%$ & $4.832^{*}$ \\
\hline $\operatorname{CAR}(-2,2)$ & $7.69 \%$ & $5.131^{*}$ \\
\hline $\operatorname{CAR}(0,2)$ & $6.31 \%$ & $4.676^{*}$ \\
\hline $\operatorname{CAR}(0,5)$ & $5.66 \%$ & $3.600^{*}$ \\
\hline $\operatorname{CAR}(0,10)$ & $4.00 \%$ & $1.989 *$ \\
\hline $\operatorname{CAR}(0,20)$ & $3.09 \%$ & 1.315 \\
\hline $\operatorname{CAR}(0,30)$ & $2.01 \%$ & 0.728 \\
\hline $\operatorname{CAR}(-10,10)$ & $7.51 \%$ & $3.131 *$ \\
\hline $\operatorname{CAR}(-40,40)$ & $9.53 \%$ & $2.190^{*}$ \\
\hline
\end{tabular}

* = Statistically significant at 0.05 level or less for a one-sided t-test

Figure 1

Daily CAR's for Canadian Target Companies

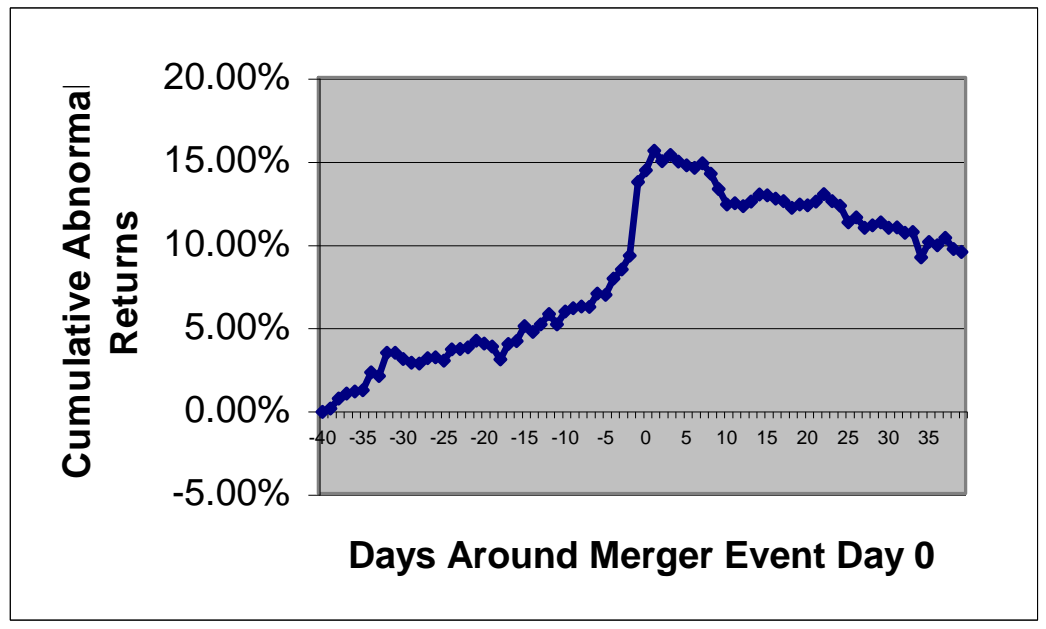

\subsection{Performance of Acquiring Firms}

We find abnormal returns for 1361 acquiring companies' shareholders as shown in Table IV and cumulative abnormal returns for the same shareholders in Table V and Figure 2. Our evidence supports positive abnormal returns. Abnormal returns start to be significant two days before the announcement. On the announcement day, shareholders of the acquirers experience $1.09 \%$ positive excess return. Shareholders continue their earnings with $0.53 \%$ excess return the day after the announcement. Two days after the takeover announcement shareholder returns turn into negative range, although negative returns become significant only four days after the announcement.

As shown in Table V and Figure 2, our holding period returns or Cumulative Abnormal Returns (CAR), also justify our alternate hypothesis that significant and positive abnormal returns go to acquirer shareholders in the first week. The shareholders of the acquiring firms earn a total of $2.01 \%$ excess returns within days -2 and +2 . Between the announcement day and the 2 days after (CAR 0,2), they earn $1.41 \%$. However after the first week returns become negative. These abnormal returns become non-significant at the end of the first week and significant and negative at three weeks and four weeks.

\section{Table IV}


Acquirer Company Abnormal Returns

\begin{tabular}{|c|c|c|c|c|c|c|}
\hline $\begin{array}{c}\text { Event } \\
\text { Day }\end{array}$ & $\begin{array}{c}\text { Abnormal } \\
\text { Return }\end{array}$ & t-statistic & & $\begin{array}{c}\text { Event } \\
\text { Day }\end{array}$ & $\begin{array}{c}\text { Abnormal } \\
\text { Return }\end{array}$ & t-statistic \\
\hline-20 & $-0.16 \%$ & -0.733 & & 1 & $0.53 \%$ & $3.148^{*}$ \\
\hline-19 & $0.34 \%$ & 1.208 & & 2 & $-0.21 \%$ & -1.430 \\
\hline-18 & $-0.01 \%$ & -0.076 & & 3 & $-0.27 \%$ & -1.598 \\
\hline-17 & $-0.11 \%$ & -0.590 & & 4 & $-0.44 \%$ & $-2.977^{*}$ \\
\hline-16 & $0.08 \%$ & 0.523 & & 5 & $-0.32 \%$ & $-2.620^{*}$ \\
\hline-15 & $0.03 \%$ & 0.186 & & 6 & $0.02 \%$ & 0.139 \\
\hline-14 & $0.07 \%$ & 0.368 & & 7 & $-0.38 \%$ & $-2.595^{*}$ \\
\hline-13 & $0.32 \%$ & 1.463 & & 8 & $-0.41 \%$ & $-2.794^{*}$ \\
\hline-12 & $0.17 \%$ & 1.380 & & 9 & $0.09 \%$ & 0.702 \\
\hline-11 & $0.10 \%$ & 0.741 & & 10 & $-0.46 \%$ & $-3.105^{*}$ \\
\hline-10 & $0.09 \%$ & 0.431 & & 11 & $0.09 \%$ & 0.489 \\
\hline-9 & $0.02 \%$ & 0.099 & & 12 & $-0.16 \%$ & -1.256 \\
\hline-8 & $-0.08 \%$ & -0.657 & & 13 & $0.02 \%$ & 0.172 \\
\hline-7 & $0.20 \%$ & 1.427 & & 14 & $-0.15 \%$ & -1.110 \\
\hline-6 & $0.03 \%$ & 0.227 & & 15 & $-0.40 \%$ & $-2.778^{*}$ \\
\hline-5 & $0.19 \%$ & 1.294 & & 16 & $-0.22 \%$ & -1.644 \\
\hline-4 & $0.09 \%$ & 0.694 & & 17 & $-0.06 \%$ & -0.418 \\
\hline-3 & $0.00 \%$ & -0.012 & & 18 & $-0.06 \%$ & -0.454 \\
\hline-2 & $0.35 \%$ & $2.226^{*}$ & & 19 & $-0.15 \%$ & -1.009 \\
\hline-1 & $0.25 \%$ & 1.547 & & 20 & $0.21 \%$ & 1.301 \\
\hline 0 & $1.09 \%$ & $4.650 *$ & & & & \\
\hline & & & & & & \\
\hline
\end{tabular}

Table V

Acquirer Company Cumulative Abnormal Returns

\begin{tabular}{|l|c|c|}
\hline CAR Range & $\begin{array}{c}\text { Abnormal } \\
\text { Return }\end{array}$ & t statistic \\
\hline $\operatorname{CAR}(-5,5)$ & $1.27 \%$ & $2.869^{*}$ \\
\hline $\operatorname{CAR}(-2,2)$ & $2.01 \%$ & $4.919^{*}$ \\
\hline $\operatorname{CAR}(0,2)$ & $1.41 \%$ & $4.764^{*}$ \\
\hline $\operatorname{CAR}(0,5)$ & $0.39 \%$ & 1.113 \\
\hline $\operatorname{CAR}(0,10)$ & $-0.76 \%$ & -1.689 \\
\hline $\operatorname{CAR}(0,20)$ & $-1.63 \%$ & $-2.269^{*}$ \\
\hline $\operatorname{CAR}(0,30)$ & $-3.73 \%$ & $-3.653^{*}$ \\
\hline $\operatorname{CAR}(-10,10)$ & $0.38 \%$ & 0.618 \\
\hline $\operatorname{CAR}(-40,40)$ & $-2.32 \%$ & -0.960 \\
\hline
\end{tabular}

$*$ = Statistically significant at 0.05 level or less for a two-sided t-test 
Figure 2

Daily CAR's for Canadian Acquiring Companies

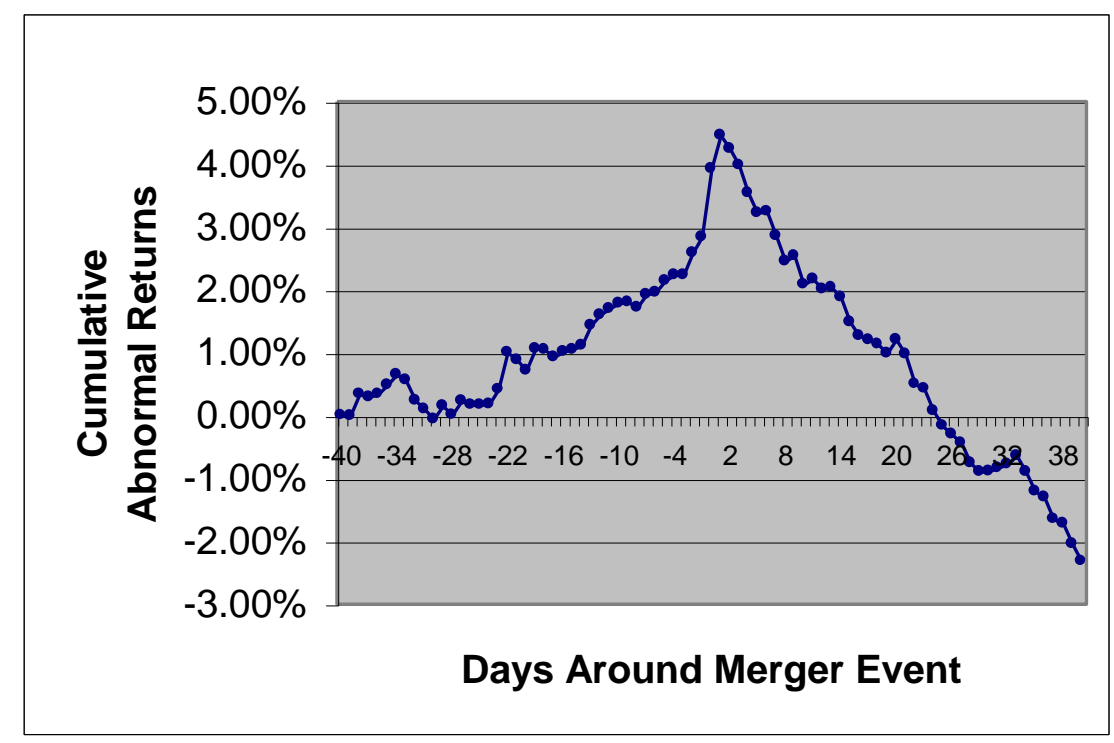

C: Performance of Acquirers buying Private versus Public Targets

We are able to separate our 1361 acquiring companies to two groups: 1261 companies, which bought publicly traded targets, and 90 companies which bought private targets. As shown in Table VII, there appears to be no difference in the number of acquirers between these groups on the percent positive returns. We find abnormal returns for these two groups of acquiring companies' shareholders as shown in Table VI and cumulative abnormal returns for the same shareholders in Table VII. As shown in Table VI and VII, we find our p-values to be insufficiently low enough, so we fail to reject our null hypothesis that there is no difference in returns. That is, we find insufficient evidence that mergers with private versus public companies result in different returns. The market seems to be unable to reward private versus public mergers differently. On the other hand, we find significant differences in the risk of the returns between acquirers who bought private versus public companies. As shown in Table VII, acquirers that bought private targets had significantly (at 0.01 level) higher standard deviations in returns than acquirers that bought public targets. For example, in CAR 0 to 30 days, the standard deviation is twice as high for acquiring public targets. This shows that there is more risk for an acquiring company to buy a private company than a public company. Indeed, without public involvement in the valuation and assessment of a private company, it makes sense that such acquiring companies face uncertainty in pricing the target and face a certain risk of poor valuation and overpaying for a company. Hence, we find support for information efficiency theory in that acquiring public targets have less risk in returns than acquiring private targets due to public availability of information about public targets.

We assert that these findings make a noteworthy contribution as most acquisitions, whether in the U.S. or Canada, are of private targets, and previous Canadian studies have not examined this aspect. 
Table VI

Difference in Mean Abnormal Returns between acquiring private targets versus public targets

\begin{tabular}{|c|c|c|c|c|c|c|c|c|}
\hline \multirow[b]{2}{*}{ Day } & \multicolumn{3}{|c|}{$\begin{array}{c}\text { Acquirers of } \\
\text { Private Targets }\end{array}$} & \multicolumn{3}{|c|}{$\begin{array}{c}\text { Acquirers of } \\
\text { Public Targets }\end{array}$} & \multicolumn{2}{|c|}{$\begin{array}{c}\text { t-test: difference in } \\
\text { Mean Returns } \\
\end{array}$} \\
\hline & $\mathbf{n}$ & Mean AR & Std Dev & $\mathbf{n}$ & Mean AR & Std Dev & t Value & $\operatorname{Pr}>|\mathbf{t}|$ \\
\hline-16 & 1271 & $0.02 \%$ & $5.79 \%$ & 90 & $1.02 \%$ & $5.17 \%$ & -1.76 & 0.0808 \\
\hline-15 & 1271 & $0.16 \%$ & $6.39 \%$ & 90 & $-1.80 \%$ & $11.37 \%$ & 1.61 & 0.1105 \\
\hline-14 & 1271 & $-0.01 \%$ & $6.59 \%$ & 90 & $1.18 \%$ & $5.82 \%$ & -1.86 & 0.0652 \\
\hline-13 & 1271 & $0.03 \%$ & $5.31 \%$ & 90 & $4.37 \%$ & $24.05 \%$ & -1.71 & 0.0909 \\
\hline-12 & 1271 & $0.12 \%$ & $4.41 \%$ & 90 & $0.79 \%$ & $4.63 \%$ & -1.33 & 0.1879 \\
\hline-11 & 1271 & $0.05 \%$ & $4.92 \%$ & 90 & $0.82 \%$ & $6.20 \%$ & -1.15 & 0.2511 \\
\hline-10 & 1271 & $-0.05 \%$ & $4.88 \%$ & 90 & $2.01 \%$ & $22.61 \%$ & -0.86 & 0.3908 \\
\hline-9 & 1271 & $0.16 \%$ & $5.54 \%$ & 90 & $-2.00 \%$ & $10.68 \%$ & 1.87 & 0.0647 \\
\hline-8 & 1271 & $-0.10 \%$ & $4.56 \%$ & 90 & $0.61 \%$ & $6.39 \%$ & -1.08 & 0.2827 \\
\hline-7 & 1271 & $0.26 \%$ & $4.58 \%$ & 90 & $-0.60 \%$ & $11.20 \%$ & 0.76 & 0.4512 \\
\hline-6 & 1271 & $-0.02 \%$ & $4.91 \%$ & 90 & $0.84 \%$ & $10.16 \%$ & -0.80 & 0.4283 \\
\hline-5 & 1271 & $0.15 \%$ & $5.28 \%$ & 90 & $0.79 \%$ & $6.85 \%$ & -0.87 & 0.3850 \\
\hline-4 & 1271 & $0.13 \%$ & $4.74 \%$ & 90 & $-0.40 \%$ & $7.21 \%$ & 0.69 & 0.4945 \\
\hline-3 & 1271 & $0.01 \%$ & $4.56 \%$ & 90 & $-0.10 \%$ & $6.14 \%$ & 0.21 & 0.8315 \\
\hline-2 & 1271 & $0.23 \%$ & $5.45 \%$ & 90 & $2.13 \%$ & $9.83 \%$ & -1.82 & 0.0726 \\
\hline-1 & 1271 & $0.18 \%$ & $5.17 \%$ & 90 & $1.22 \%$ & $12.55 \%$ & -0.78 & 0.4355 \\
\hline 0 & 1271 & $0.99 \%$ & $6.44 \%$ & 90 & $2.37 \%$ & $23.20 \%$ & -0.56 & 0.5773 \\
\hline 1 & 1271 & $0.46 \%$ & $6.00 \%$ & 90 & $1.47 \%$ & $8.70 \%$ & -1.08 & 0.2820 \\
\hline 2 & 1271 & $-0.10 \%$ & $4.75 \%$ & 90 & $-1.20 \%$ & $11.13 \%$ & 0.88 & 0.3805 \\
\hline 3 & 1271 & $-0.20 \%$ & $4.41 \%$ & 90 & $-1.80 \%$ & $17.37 \%$ & 0.88 & 0.3793 \\
\hline 4 & 1271 & $-0.40 \%$ & $4.89 \%$ & 90 & $-0.60 \%$ & $10.32 \%$ & 0.19 & 0.8524 \\
\hline 5 & 1271 & $-0.20 \%$ & $4.23 \%$ & 90 & $-1.50 \%$ & $6.77 \%$ & 1.80 & 0.0755 \\
\hline
\end{tabular}

Table VII

Difference between acquirers of private targets

versus public targets for mean holding period returns and Standard Deviations

\begin{tabular}{|c|c|c|c|c|c|c|c|c|c|c|}
\hline \multirow{2}{*}{$\begin{array}{c}\text { Holding } \\
\text { Returns } \\
\text { CAR's }\end{array}$} & \multicolumn{3}{|c|}{$\begin{array}{c}\text { Acquirers of } \\
\text { Private Targets }\end{array}$} & \multicolumn{3}{|c|}{$\begin{array}{c}\text { Acquirers of } \\
\text { Public Targets } \\
\end{array}$} & \multicolumn{2}{|c|}{$\begin{array}{c}\text { Difference in } \\
\text { Mean Returns } \\
\end{array}$} & \multicolumn{2}{|c|}{$\begin{array}{c}\text { Difference in } \\
\text { Standard Deviation }\end{array}$} \\
\hline & $\mathbf{n}$ & Mean AR & Std Dev & $\mathbf{n}$ & Mean AR & Std Dev & t Value & $\operatorname{Pr}>|t|$ & F Value & $\operatorname{Pr}>\mathbf{F}$ \\
\hline $\operatorname{CAR}(0,2)$ & 1271 & $1.32 \%$ & $9.66 \%$ & 90 & $0.43 \%$ & $8.76 \%$ & 0.92 & 0.3598 & 1.22 & 0.2344 \\
\hline CAR(-2,2) & 1271 & $1.73 \%$ & $11.27 \%$ & 90 & $1.42 \%$ & $8.82 \%$ & 0.31 & 0.7562 & 1.63 & $0.0038 *$ \\
\hline $\operatorname{CAR}(-5,5)$ & 1271 & $1.19 \%$ & $16.38 \%$ & 90 & $2.14 \%$ & $10.67 \%$ & -0.78 & 0.4376 & 2.36 & $<0.0001 *$ \\
\hline $\operatorname{CAR}(0,10)$ & 1271 & $-0.60 \%$ & $16.00 \%$ & 90 & $0.05 \%$ & $12.24 \%$ & -0.49 & 0.6246 & 1.71 & $0.0016^{*}$ \\
\hline $\operatorname{CAR}(0,5)$ & 1271 & $0.50 \%$ & $12.38 \%$ & 90 & $0.35 \%$ & $12.46 \%$ & 0.11 & 0.9129 & 1.01 & 0.9056 \\
\hline $\operatorname{CAR}(0,20)$ & 1271 & $-1.80 \%$ & $26.61 \%$ & 90 & $-0.90 \%$ & $14.80 \%$ & -0.49 & 0.6222 & 3.23 & $<0.0001^{*}$ \\
\hline $\operatorname{CAR}(0,30)$ & 1271 & $-3.70 \%$ & $38.43 \%$ & 90 & $-2.50 \%$ & $19.32 \%$ & -0.51 & 0.6099 & 3.96 & $<0.0001 *$ \\
\hline CAR $(-10,10)$ & 1271 & $0.28 \%$ & $23.05 \%$ & 90 & $1.68 \%$ & $15.93 \%$ & -0.78 & 0.4399 & 2.09 & $<0.0001^{*}$ \\
\hline $\operatorname{CAR}(-40,40)$ & 1271 & $-2.90 \%$ & $88.00 \%$ & 90 & $-3.30 \%$ & $33.39 \%$ & 0.09 & 0.9249 & 6.94 & $<0.0001^{*}$ \\
\hline \begin{tabular}{|l|} 
Percent \\
Positive \\
CAR $(\mathbf{0 , 2})$ \\
\end{tabular} & \multicolumn{3}{|c|}{$51.1 \%$} & \multicolumn{3}{|c|}{$53.2 \%$} & & & & \\
\hline
\end{tabular}

* Significance at .05 level or less with a two-sided t-test. 


\section{Conclusion}

We investigate the announcement effects of mergers and acquisitions on shareholders' returns between 1994 and 2000. Our results show that both the target and the acquiring company shareholders earn significant and positive abnormal returns for two-day holding period starting with the announcement day.

In the context of a worldwide merger boom during the 1990's, we find that mergers and acquisitions have benefited both target and acquirer company shareholders. It is consistent with many findings that mergers do pay. Despite the merger boom, the CAR returns of $9.53 \%$ to target shareholders that we find do not compare as high as the returns found in previous Canadian studies, which ranged from 9 to 23 percent. Our acquirer sample of 1361 acquiring companies is the largest sample for Canadian merger studies. While we report positive abnormal returns for acquiring shareholders during the announcement, these positive returns are fleeting beyond five days after the announcement. Returns after which become significant losses for acquiring shareholders. This too, is consistent with studies reporting significant negative returns to acquiring shareholders. We find that creating value for acquiring shareholders is a 50-50 percent proposition, and the probability of succeeding diminishes soon, five days after announcement. There are better chances of creating value for target shareholders, 61 percent. For the business practitioner, creating value through acquisition requires an understanding of what truly creates value and the ability to realize value paramount. Bruner (2002) suggests "value is created by focus, relatedness and adherence to strategy."

Interestingly, we study the impact of acquiring public versus private targets on shareholder returns. We explore the ability of the market to value acquisitions under asymmetric information conditions in which the public knows far less about the private target than does the acquirer. We find non-significant differences in returns to acquirers buying public versus target companies. This result is comparable with the findings of Chang, 1998. He concludes that there were indistinguishable returns between the purchase of private versus public targets with cash offers. Moreover, in stock offers, he finds significant differences: buying private targets earned positive abnormal returns, and buying public targets earned negative abnormal returns. However, we find significantly higher risk for acquirers buying private targets versus public targets. The implication for the executive is for him or her to value the risk and returns of acquisition of a private and public company differently. Acquiring a private firm is more risky, and depending on the method of payment as found by Chang, 1998, does not pay more than acquiring a public company.

Reflecting on some limitations of this study allows us to give direction to future research. One limitation is that we examine one explanatory variable, which is acquisition of public versus private companies on shareholder returns. Another limitation is that we do not examine the impact of cash and stock payment on the different returns to acquirers buying private versus public targets. In the future, we will examine other explanatory variables on shareholder returns such as method of payment, type of merger, and financial performance.

The consistent findings of gains to acquirers and targets found in Canadian studies still support the US studies and continue to be generalizable because there are also similarities between Canadian and US capital markets. Limits to generalizability of these findings include: Canada being a different country having different capital markets and a different time period. We find that these differences justify our pursuit of this study. Indeed, other countries undoubtedly have differences in capital markets, industry characteristics and regulations that pertain to mergers just like Canada does with the United States. Hence, this study is generalizable to the extent that such country differences do affect the impact of mergers on returns. This paper provides a comprehensive update of the Canadian merger literature during this important period of 1994-2000.

\section{References}

1. Amihud, Yakov, Dodd, P. and Weinstein, M., "Conglomerate Mergers, Managerial Motives and Stockholder Wealth", Journal of Banking and Finance, 10 (October 1986), pp.401-410.

2. $\quad$ Arrow, K.J, Vertical Integration and Communication”, Bell Journal of Economics, Spring 1975, pp. 173183. 
3. Asquith, Paul, "Merger Bids, Uncertainty, and Stockholder Returns", Journal of Financial Economics, 11 (April 1983), pp. 51-83.

4. Baldwin, J.R. and Gorecki, P.K.,"Mergers and the Competitive Process", Working Paper, Statistics Canada, 1990.

5. Berger, Philip G. and Ofek, Eli, "Diversification's effect on firm value", Journal of Financial Economics 37, (1995), pp. 39-65.

6. Berry, P, "A Comparison of the Premiums in Vertical and Horizontal Mergers", ASAC-IFSAM 2000 Conference Proceedings, July 8-11, Montreal, Canada Administrative Sciences Association of Canada.

7. Bradley, Michael, A. Desai, and E. Han Kim, "The Rationale Behind Interim Tender Offers: Information or Synergy?”, Journal of Financial Economics, 11 (April 1983), pp.183-206.

8. Bradley, M. and L. M. Wakeman, "The Wealth Effects of Targeted Share Repurchases", Journal of Financial Economics, (April 1983), pp.301-328.

9. Bruner, Robert F., "Does M\&A Pay? A Survey of Evidence for the Decision-Maker", Journal of Applied Finance, 12 (1) (Spring/Summer 2002), pp. 48-68.

10. Calvet, A.L. and J. Lefoll, "Information Asymmetry and Wealth Effect of Canadian Corporate Acquisitions." The Financial Review, 22 (4) (November 1987), pp.415-431.

11. Chang, Saeyoung, "Takeovers Of Privately Held Targets, Methods Of Payment, And Bidder Returns", Journal of Finance, 53, 2 (April 1998), pp.773-784.

12. Dennis, Debra K. and McConnell, J. "Corporate Mergers and Security Returns", Journal of Financial Economics, 16 (June 1986), pp.143-187.

13. Dodd, Peter R. and R S. Ruback, "Tender Offers and Stockholder Returns: An Empirical Analysis", Journal of Financial Economics, 5 (December 1977), pp.351-373.

14. Dodd, Peter R. "Merger Proposals, Management Discretion and Stockholder Wealth", Journal of Financial Economics, 8 (June 1980), pp.105-137.

15. Doukas, John and N. Travlos, "The Effect of Corporate Multinationalism on Shareholders' Wealth: Evidence from International Acquisitions", Journal of Finance, 43, 5 (December 1988), pp.1161-1175.

16. Eckbo, Espen B. "Horizontal Mergers, Collusion and Shareholder Wealth", Journal of Financial Economics, 11 (April 1983), pp. 241-273.

17. Eckbo, Espen B. "Mergers and the Market for Corporate Control: The Canadian Evidence", Canadian Journal of Economics, 19 (2) (May 1986), pp.236-260.

18. Eckbo, Espen B. "Mergers and the Value of Antitrust Deterrence", Journal of Finance. 47,3. Papers and Proceedings of the Fifty-Second Annual Meeting of the American Finance Association, New Orleans, Louisiana, January 3-5, 1992. (July, 1992), pp. 1005-1029.

19. Eger, Carol E. "An Empirical Test of the Redistribution Effect in Pure Exchange Mergers", Journal of Financial and Quantitative Analysis 18 (December 1983), pp. 547-72.

20. Eun, Cheol S., R. Kolodny, and C. Scheraga, "Cross-Border Acquisitions and Shareholder Wealth: Tests of the Synergy and Internalization Hypotheses", Journal of Banking and Finance, 20(9) (November 1996), pp.1559-1582.

21. Firth, Michael "Takeovers, Shareholder Returns, and the Theory of the Firm", Quarterly Journal of Economics 94 (March 1980), pp. 235-60.

22. Fishman, Michael J. "Preemptive Bidding and the Role of the Medium of Exchange in Acquisitions", Journal of Finance, 44 , No.1 (March 1989).

23. Franks, J.R., R. S. Harris, and C. Mayer, "Means of Payment in Takeovers: Results for the United Kingdom and the United States", (ed.) Corporate Takeovers, Causes and Consequences, (Chicago: University of Chicago Press, 1988).

24. Golbe, Devra L., and Lawrence J. White. "Catch a Wave: The Time Series Behavior of Mergers", Review of Economics and Statistics. 75, Bi, 3. (August 1993), pp. 493-499.

25. Lang, Larry H.P. and Rene M. Stulz, "Tobin's q, corporate diversification, and firm performance", Journal of Political Economy 102, (1994), pp. 1248-1280.

26. Jabbour, Alain R. and Abolhassan Jalilvand and Jeannette A. Switzer. "Pre-bid price run-ups and insider trading activity: Evidence from Canadian acquisitions", International Review of Financial Analysis. 9,1. (2000) pp. 21-43. 
27. Jarrell, Gregg and M. Bradley, "The Economic Effects of Federal and State Regulations of Cash Tender Offer", Journal of Law and Economics, 23 (1980), pp371-407.

28. Jensen, Michael C. and R S. Ruback, "The Market for Corporate Control. The Scientific Evidence", Journal of Financial Economics, 11 (April 1983), pp. 5-50.

29. Keown, Arthur and J. Pinkerton, "Merger Announcements and Insider Trading Activity", Journal of Finance, 36 (September 1981), 855-869.

30. Levy, H., and M. Sarnat, "Diversification, Portfolio Analysis and the Uneasy case for Conglomerate Mergers", Journal of Finance, September 1970, pp. 795-802.

31. Lewellen, Wilbur, O, "A Pure Financial Rational for the Conglomerate Merger.", Journal of Finance 26 (May 1971), pp. 521-537.

32. Malatesta, Paul H, "The Wealth Effect of Merger Activity and the Objective Functions of Merging Firms", Journal of Financial Economics, 11 (1983), pp.155-181.

33. Maquieira, Carlos P., William L. Megginson and Lance Nail, "Wealth Creation Versus Wealth Redistributions In Pure Stock-For-Stock Mergers", Journal of Financial Economics, 48, (1988), pp. 3-33.

34. Masse, Isidore, R. Hanrahan, and J. Kushner, "The Effect of the Method of Payment on Stock Returns in Canadian Tender Offers and Merger Proposals for Both Target and Bidding Firms", Quarterly Journal of Business and Economics, Autumn 1990, Vol. 29 Issue 4, pp.102.

35. Manzon, Gil B., D. Sharp, and N. Travlos, "An Empirical Study of the Consequences of U.S. Tax Rules for International Acquisitions by U.S. Firms", Journal of Finance, 49, 5 (December 1994), pp.1893-1904.

36. Pastena, Victor S. and S. Lilien, "Market Manifestation of Nonpublic Information Prior to Mergers: The Effect of Ownership Structure In-mu Haw", Accounting Review, Vol. 65 Issue 2 (April 1990), pp. 432-452.

37. Pryor, Frederic L. "Dimensions of the worldwide merger boom", Journal of Economic Issues, 35, 4. Lincoln. Dec. 2001. pp. 825-840.

38. Schipper, Katherine and R. Thompson, "Evidence on the Capitalized Value of Merger Activity For Acquiring Firms", Journal of Financial Economics, 11 (April 1983), pp.85-119.

39. Travlos, Nikolaos, G. "Corporate Takeover Bids, Methods of Payment, and Bidding Firms' Stock Returns", Journal of Finance, 42(4) (September 1987) pp. 943-63.

Notes 
Notes 